\title{
FOOD SAFETY THROUGH APPLICATION OF AN E-LEARNING PLATFORM
}

\author{
Mihaela Adriana, TITA ${ }^{1}$, Otto, KETNEY ${ }^{1}$, Tamosaitiene, LORETA ${ }^{2}$ \\ ${ }^{1}$ Lucian Blaga" University of Sibiu, Sibiu, Romania, e-mail: tita_mihaeladriana@yahoo.com \\ ${ }^{2}$ Klaipedos paslaugu ir vreslo mokykla, Lithuania
}

\begin{abstract}
The paper investigates the effectiveness of a continuing online education course for the professionals, who provides information on the food safety working group from "Lucian Blaga" University of Sibiu, formed by students (specialization: Engineering and Management in Public Food and Agro-tourism), persons looking for a job (unemployed) and people who works in the food industry. Piloting materials was made both face to face and online. The knowledges was measured using evaluation tests after each lesson and through a final assessment test. The results of the promotion rate was over $90 \%$, which indicates a high efficiency in terms of piloting materials adapted by teachers from the "Lucian Blaga" University.
\end{abstract}

KEY WORDS: evaluation, tests, piloting, food safety

\section{INTRODUCTION}

Food poisoning has been described as one of the most common problems of the contemporary world (Notermans, Zwietering, \& Mead, 1994) and their incidence has increased significantly (Mossel, 1989; Todd, 1989). The number of food poisoning has increased, revealing that most of them are caused by improper handling (Adams \& Motarjemi, 1999). Therefore, appropriate handling practices are essential for preventing food poisoning in food production and distribution (Campos et al., 2009; de Sousa, 2008). Increased incidence of food poisoning has been attributed to several different factors, including population growth, rapid urbanization, changes in food preparation habits, increased food consumption outside the home and a lack of food safety training and education among consumers, employees working in public food. (Motarjemi \& Käferstein, 1999).

Regular training is thus considered the most important way to prevent or mitigate contamination of food by improving the employees skills. Such training should be accompanied by regular inspection of workers activities (Acikel et al., 2008; Campos et al., 2009; Capunzo et al., 2005; de Sousa, 2008). The employees training is considered an important component of a corporate image, both internal and external competitiveness (DiPietro, 2005).

Continuous training has traditionally been done through workshops and professional conferences, but these options can be expensive, time consuming and sometimes awkward (Brandt, Sapp, \& Campbell, 1996; Garrison, Schardt, \& Kochi, 2000; Kolasa, Daugherty, Jobe, \& Miller, 2001; Schardt, Garrison, \& Kochi, 2002). Lately is a popularity in terms of internet use, therefore online courses have emerged as a convenient way to gain trust in continuing education (BeffaNegrini, Cohen \& Miller 2002; Brug, Oenema, \& Campbell,
2003; Garrison et al., 2000; Mary Schmitt Belding Ardery PhD RN \& Gail, 2004; Santerre, 2005).

Online courses change traditional content transfer, which affects the development of online courses in many ways. However, Gabriel and Longman (2004) stressed the need for developers to understand e-learning technology in teaching online and the importance of providing technical assistance to learners.

The aim of this study was to develop and evaluate the effectiveness of a course "Introduction to HACCP and establish a food security plan based on HACCP" through online platform European Food Safety Staff (www.foodsafety.ro). The course was developed under the Leonardo da Vinci, Transfer of Innovation 2013-1-RO1-LEO05-28756 LLP-LDV / TOI / 2013 / EN / 007 Development 2007-2013, also Food Safety European Training platform for training in e-learning system which aims (Training, 2015):

- To elaborate learning tools through which students and young employees to acquire basic skills in the food industry and public alimentation;

- To develop basic skills and professional development using seminars and training lessons for schools (students and teachers) and companies in the field above mentioned;

- To improve the quality of training in food safety by providing elaborated and efficient teaching materials;

- To contribute at the increasing the motivation of students, young workers and teachers on professional development, giving them an accessible, free and updated learning tool;

- To reduce the risks of food safety throughout the food chain, by providing these innovative and current learning tools;

- To transfer the project results at European Union level; 
- To ensure an e-learning system with the perspective of a future certifications and recognition of qualifications in the European Union.

The consortium which operates the project consists of 10 partners, of which three partners are from Romania, 5 partners from Belgium, one from Turkey and one from Lithuania.

I also used a SWOT analysis, wich is a simple, yet powerful management with wich we can analyze the key aspects in the evaluation of online education course.

\section{MATERIALS AND METHODS}

The locations for this research were in Lucian Blaga University of Sibiu, Faculty of Agricultural, Food Industry and Environmental Protection Sibiu.

Module III which was piloted in the project of "Lucian Blaga" University has 12 chapters, addressing themes of the day, in terms of food safety. The material by which was made piloting has been improved by teachers who participated in this project.

Piloting of materials in this project was made with a group in the "Lucian Blaga" University of Sibiu, consisting of 136 participants, both in the online and face to face.

\section{RESULTS AND DISCUSSION}

At this course have signed up 136 participants, of which 104 people were female (76.5\% of participants) and 32 male persons (23.5\% of participants). From the statistical point of view between the female and male were not significant differences at the degree of graduation.

Most participants, respectively 88 persons are domiciled in urban areas (64.7\% of participants) and 48 in rural areas (35.3\% of participants), however, residence did not affect the graduate degree.

Regarding the workplace 48 of the participants are students (35.3\%), 63 employees in the food industry and adjacent sectors $(46.3 \%)$, while 25 were persons looking for a job (18.4\%). However position in the labor market did not influence the results.

Table 2. The frequency of qualifications received

\begin{tabular}{|c|c|c|}
\hline Note & Frequency & $\begin{array}{c}\text { Percent } \\
(\boldsymbol{\%})\end{array}$ \\
\hline 2,00 & 7 & 5.1 \\
\hline 4,00 & 4 & 2,9 \\
\hline 5,00 & 3 & 2,2 \\
\hline 6,00 & 1 & 0,7 \\
\hline 7,00 & 2 & 1,5 \\
\hline 8,00 & 33 & 24,3 \\
\hline 9,00 & 25 & 18,4 \\
\hline 10,00 & 61 & 44,9 \\
\hline Total & 136 & 100,0 \\
\hline
\end{tabular}

Following SWOT analysis we obtained the following results:

\begin{tabular}{|c|c|}
\hline Strong points & Weak points \\
\hline Novelty in organizing and & Insufficient information on \\
conducting educational process; & market demand; \\
Teacher with experience and & The lack of structures to \\
highly qualified initiatives & integrate regional innovation \\
stimulating factor, creativity and & system; \\
originality; & Lack of continuous training and \\
counseling activities. \\
Information, Internet access; \\
Access to online libraries;
\end{tabular}

Develop educational materials and scientific articles;

Information Resources documented - database;

Develop technological transfer of results.

\begin{tabular}{|c|c|}
\hline Opportunites & Threats \\
\hline $\begin{array}{c}\text { Provide an alternative to } \\
\text { education; } \\
\text { Programme of international } \\
\text { cooperation; } \\
\text { Financing sources for initial and } \\
\text { continuing education } \\
\text { infrastructure; } \\
\text { Solving the underlying problems } \\
\text { in the labor market and } \\
\text { increasing related services to } \\
\text { employers. }\end{array}$ & $\begin{array}{c}\text { Rapid wear of PCs; } \\
\text { Reduced effectiveness of } \\
\text { continuing vocational training } \\
\text { in the absence of adequate } \\
\text { forecasting labor market } \\
\text { developments; } \\
\text { Frequent changes of } \\
\text { legislation; } \\
\text { Lack of motivation of persons } \\
\text { covered; } \\
\text { Inconsistency between the } \\
\text { Romanian legislation and } \\
\text { European legislation. }\end{array}$ \\
\hline
\end{tabular}

\section{CONCLUSIONS}

The participants at the project were considered promoted if they took minimum grade 5 , however the promotion rate was $92 \%$, which indicates that the material piloting in the project was successful.

The results between all professional groups regarding the piloting of materials indicates that the course was effective in consolidating knowledge and has positive implications for future courses based on E-learning platform Food Safety European Training. Evaluation tests indicated that participants liked the format and was considered useful for their work. Having regard of improved results obtained and positive responses to the evaluation questions appear to be an attractive alternative to traditional options for professionals who work in the food industry and its related domains.

Developing and providing training courses are crucial to achieve behavioral changes and improve skills and knowledge in food safety. The course "Introduction to HACCP and setting a food security plan based on HACCP" was reviewed and is publicly available on the platform of European E-learning Food Safety Staff. (www.food-safety.ro).

\section{ACKNOWLEDGEMENTS}

This work was supported by Leonardo da Vinci, Transfer of Innovation 2013-1-RO1-LEO05-28756 LLP-LdV/TOI/2013/ RO/007Development 2007 - 2013

\section{REFERENCES}

1. Acikel, C. H., Ogur, R., Yaren, H., Gocgeldi, E., Ucar, M., \& Kir, T. (2008). The hygiene training of food handlers at a teaching hospital. Food Control, 19(2), 186-190.

2. Adams, M., \& Motarjemi, Y. (1999). Basic food safety for health workers: World Health Organization.

3. Beffa-Negrini, P. A., Cohen, N. L., \& Miller, B. (2002). Strategies to motivate students in online learning environments. Journal of Nutrition Education and Behavior, 34(6), 334-340.

4. Brandt, K. A., Sapp, J. R., \& Campbell, J. M. (1996). "Current topics in health sciences librarianship": a pilot program for network-based lifelong learning. Bulletin of the Medical Library Association, 84(4), 515. 
5. Brug, J., Oenema, A., \& Campbell, M. (2003). Past, present, and future of computer-tailored nutrition education. The American Journal of Clinical Nutrition, 77(4), 1028S-1034S.

6. Campos, A. K. C., Cardonha, Â. M. S., Pinheiro, L. B. G., Ferreira, N. R., de Azevedo, P. R. M., \& Stamford, T. L. M. (2009). Assessment of personal hygiene and practices of food handlers in municipal public schools of Natal, Brazil. Food Control, 20(9), 807-810.

7. Capunzo, M., Cavallo, P., Boccia, G., Brunetti, L., Buonomo, R., \& Mazza, G. (2005). Food hygiene on merchant ships: the importance of food handlers' training. Food Control, 16(2), 183-188.

8. De Sousa, C. P. (2008). The impact of food manufacturing practices on food borne diseases. Brazilian Archives of Biology and Technology, 51(4), 815-823.

9. Dipietro, R. B. (2005). Return on investment in managerial training: does the method matter? Journal of Foodservice Business Research, 7(4), 79-96.

10. Gabriel, M., \& Longman, S. (2004). Staff Perceptions of E-Learning in a Community Health Care Organization. Online Journal of Distance Learning Administration, 7(3).

11. Garrison, J. A., Schardt, C., \& Kochi, J. K. (2000). Webbased distance continuing education: a new way of thinking for students and instructors. Bulletin of the Medical Library Association, 88(3), 211.

12. Kolasa, K. M., Daugherty, J. E., Jobe, A. C., \& Miller, M. G. (2001). Virtual seminars for medical nutrition education: case example. Journal of nutrition education, 33(6), 347-351.

13. Mary Belding Schmitt RN, B., \& Gail Ardery PhD, R. (2004). Challenges of web-based education in educating nurses about evidence-based acute pain management practices for older adults. The Journal of Continuing Education in Nursing, 35(3), 121.

14. Mossel, D. (1989). Food safety and the need for public reassurance. Food Science and Technology Today, 3, 2-6.

15. Motarjemi, Y., \& Käferstein, F. (1999). Food safety, Hazard Analysis and Critical Control Point and the increase in foodborne diseases: a paradox? Food Control, 10(4), 325-333.

16. Notermans, S., Zwietering, M., \& Mead, G. (1994). The HACCP concept: identification of potentially hazardous micro-organisms. Food microbiology, 11(3), 203-214.

17. Santerre, C. R. (2005). X-train: teaching professionals remotely. The Journal of nutrition, 135(5), 1248-1252.

18. Schardt, C. M., Garrison, J., \& Kochi, J. K. (2002). Distance education or classroom instruction for continuing education: who retains more knowledge? Journal of the Medical Library Association, 90(4), 455.

19. Todd, E. C. (1989). Costs of acute bacterial foodborne disease in Canada and the United States. International journal of food microbiology, 9(4), 313-326.

20. Training, E. F. S. (2015). Despre proiect « European Food Safety Training. Retrieved 23.06.2015, 2015, from http://efst.eu/ro/about-the-project/ 